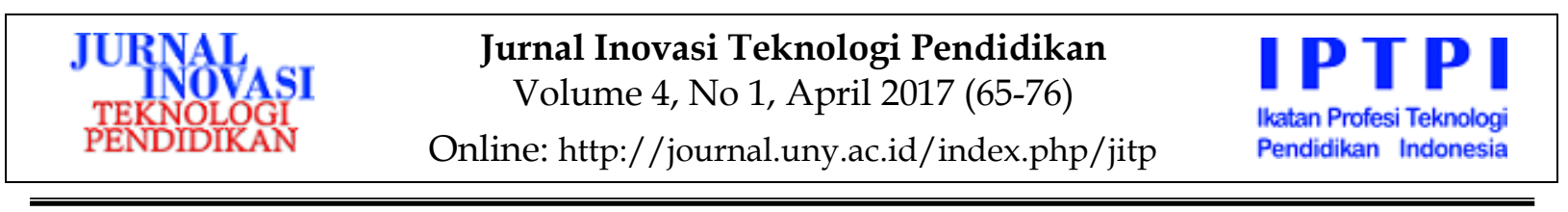

\title{
PENGEMBANGAN MODEL BLENDED LEARNING MENGGUNAKAN APLIKASI EDMODO UNTUK MATA PELAJARAN GEOGRAFI SMA
}

\author{
Muhammad Alwan \\ Sekolah Tinggi Agama Islam (STAI) Darul Kamal \\ muhammadalwan402@gmail.com
}

\begin{abstract}
Abstrak
Tujuan penelitian ini adalah untuk menghasilkan: (1) model blended learning menggunakan Edmodo, (2) tingkat kelayakan model blended learning menggunakan Edmodo pada mata pelajaran geografi, (3) keefektifan model blended learning dengan menggunakan Edmodo pada mata pelajaran geografi. Penelitian ini adalah penelitian dan pengembangan (R\&D) yang menggunakan model ADDIE. Prosedur pengembangan meliputi tahap analisis, desain, pengembangan, implementasi, dan evaluasi. Tahap analisis dan desain, dilakukan survei di lapangan untuk menganalisis kebutuhan siswa. Tahap desain disesuaikan dengan kebutuhan dalam kegiatan pembelajaran. Tahap pengembangan, validasi ahli model dan materi, kemudian dilakukan revisi produk. Tahap implementasi di kelas XI IPS SMA Assalaam pada 17 siswa. Hasil penelitian ini adalah sebagai berikut. (1) Model blended learning menggunakan aplikasi Edmodo berdasarkan tahapan komponen-komponen model. (2) Model blended learning dinyatakan layak berdasarkan hasil validasi ahli materi dengan skor 3,65 dan ahli model dengan skor 3,64 dengan kategori sangat baik. (3) Keefektifan model blended learning dibuktikan melalui peningkatan hasil belajar siswa dari 55,29 menjadi 88,65. Respon siswa secara umum menanggapi positif.
\end{abstract}

Kata Kunci: model blended learning, Edmodo, geografi

\section{DEVELOPING A BLENDED LEARNING MODEL USING THE EDMODO APPLICATION IN GEOGRAPHY SUBJECT MATTER OF SENIOR HIGH SCHOOLS}

\author{
Muhammad Alwan \\ Sekolah Tinggi Agama Islam (STAI) Darul Kamal \\ muhammadalwan402@gmail.com
}

\begin{abstract}
This research study aims to produce (1) the blended learning model using Edmodo which can improve learning outcomes and motivation in geography subject matter, (2) the appropriateness level of the blended learning model using Edmodo which can improve learning outcomes and motivation in geography subject matter, and (3) the effectiveness of the blended learning model using Edmodo in geography subject matter. This study was research and development (RED) using the ADDIE model. The procedure of the development included the steps of analysis, design, development, implementation, and evaluation. In the analysis and design steps, a survey was conducted in the field to analyze the student's needs in the learning. The development step, a validation was done by the model and materials experts which resulted in the initial revision of the product. In the implementation step, the teaching and learning in class XI social sciences of SMA Assalaam to 17 students. The result of the study is as follows. (1) The blended learning model using the Edmodo application viewed from its components. (2) The blended learning model using the Edmodo application fulfills the appropriateness criteria based on the result of the validity test from the material expert with the mean score of 3.65 and that from the model expert with the mean score of 3.64 which is in a very good category. (3) The effectiveness of the blended learning model was proved by the increasing learning achievements of the students from 55.29 to 88.65. In general, the students responded to the blended learning model positively.
\end{abstract}

Keywords: blended learning model, Edmodo, geography 


\section{Pendahuluan}

Pada hakikatnya bahwa geografi tidak hanya sebatas mengkaji tentang permukaan bumi, akan tetapi kajian goegrafi lebih luas daripada itu, geografi membahas berbagai hal yang ada dipermukaan bumi, di luar bumi, bahkan luar angkasa pun menjadi objek pembahasan ilmu geografi. Yeates dan Hagget (1979) (Soegimo \& Ruswanto, 2009, p. 2) menjelaskan bahwa geografi merupakan ilmu pengetahuan tentang perkembangan nasional, pengujian terhadap teori-teori yang menjelaskan serta memperkirakan distribusi spasial dan lokasi berbagai karakteristik permukaan bumi. Selain itu, Fielding (1974) (Soegimo \& Ruswanto, 2009, p. 2) juga menambahkan bahwa geografi merupakan studi tentang lokasi, tatanan fenomena pada permukaan bumi, dan proses-proses yang menyebabkan distribusi fenomena tersebut.

Pembelajaran geografi sebagai pengetahuan yang kompleks secara umum memiliki tujuan agar siswa pada khususnya dapat memahami pola spasial, lingkungan, dan kewilayahan serta prosesproses yang berkaitan dengan hal tersebut, selanjutnya agar siswa menguasai keterampilan dasar dalam memperoleh data dan informasi, mengkomunikasikan dan menerapkan pengetahuan geografi, serta untuk dapat menampilkan perilaku peduli terhadap lingkungan hidup dan memanfaatkan sumber daya alam secara arif serta memiliki toleransi terhadap keberagaman budaya masyarakat.

Agar dapat mencapai tujuan tersebut maka perlu adanya inovasi baik dari model pembelajaran, metode, dan media yang diterapkan dalam proses pembelajaran yang tentu saja diusahakan sesuai dengan tingkat pendidikan siswa serta yang relevan dengan karakteristik siswa tersebut. Ketepatan dalam memilih model, metode, dan media sangat besar pengaruhnya bagi siswa dalam upaya memahami konsep-konsep pembelajaran geografi yang menekankan pada bagaimana siswa memahami gejala alam seperti litosfer, pedosfer, dan lain sebagainya. Penyajian pembelajaran yang dilakukan dengan menghadirkan teks disertai gambar, video tentang beberapa analisis dampak terhadap lingkungan dalam suatu pembelajaran online membuat siswa menjadi lebih semangat.

Darmawan (2014, p. 25) pembelajaran online merupakan salah satu bentuk inovasi pembelajaran modern saat ini, dimana banyak bermunculan istilah pembelajaran jarak jauh atau istilah lain dikenal dengan distance learning yang memiliki konsep utama menekankan pembelajaran yang terpisah antara pendidik dan siswa. Munculnya gagasan pembelajaran online tidak lepas dari peran teknologi yang semakin mengalami kemajuan, salah satunya adalah dari perangkat komunikasi yang saat ini banyak bermunculan seperti smartphone, android dan lain sebagainya.

Kemunculan Smartphone dan Android bertujuan memberikan kemudahan untuk mengakses segala informasi yang dibutuhkan oleh user yang dapat diakses dimana saja dan kapan saja, akan tetapi dengan kecanggihan yang dimiliki keduanya, masyarakat hanya menggunakan smartphone dan android untuk mengakses media sosial. Hal tersebut diperkuat berdasarkan hasil riset yang dilakukan oleh Wibisono dari Asosiasi Penyelenggara Jasa Internet Indonesia (2014, p. 15) yang menemukan bahwa pengguna internet di Indonesia masih belum serius memanfaatkan kekuatan teknologi untuk kegiatan produktif, sebagaimana seperti tergambar dalam Gambar 1.

Berdasarkan gambar tersebut, menunjukan bahwa jejaring sosial menempati urutan teratas yang paling sering dikunjungi oleh pengguna internet. Sedangkan distance learning berada pada urutan terakhir yang paling sering dikiunjungi.

Namun ada beberapa media sosial yang khusus di terbitkan untuk pendidikan, salah satunya adalah Edmodo, munculnya media sosial ini tentunya akan dapat membantu dunia pendidikan pada umumnya, siswa, dan guru pada khususnya. Nee (2014, p. 22) Edmodo merupakan media 
sosial atau jaringan sosial pribadi artinya dikhususkan untuk pendidikan, tujuannya untuk meningkatkan mutu pendidikan yang lebih baik, yaitu terbangunnya interaksi antara siswa dengan guru, karena sebagai social networking, Edmodo merupakan platform yang hampir sama dengan facebook, sehingga siswa akan sangat familiar dan tertarik ketika mengikuti pembelajaran melalui Edmodo. Akan tetapi Edmodo lebih aman apabila dibandingkan dengan jejaring sosial lainnya seperti facebook, twitter, dan lain sebagainya. Karena Edmodo tidak dapat diakses oleh siswa-siswa yang lainnya, terkecuali siswa yang telah diberikan kode oleh guru.
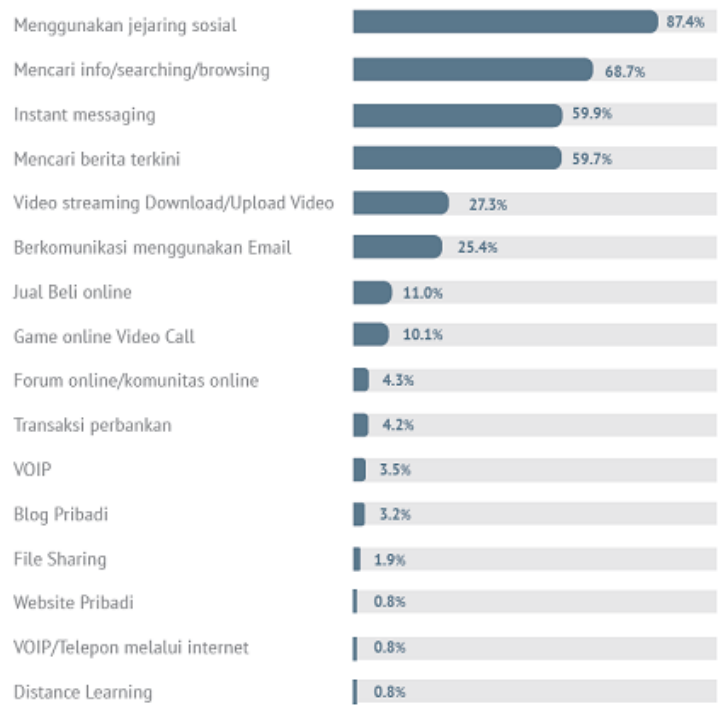

Gambar 1. Situs paling sering Diakses

(Sumber: APJII, 2014)

Pemanfaatan media dan saranasarana di sekitar yang masih kurang juga menjadi salah satu factor yang membuat siswa pasif dalam kegiatan belajar mengajar. Karena hanya beberapa siswa yang aktif dan kebanyakan siswa masih kurang aktif dalam kegiatan belajar mengajar. Pada kenyataannya siswa sangat ingin untuk bertanya, karena siswa hanya disuguhkan dengan materi verbal saja dan beberapa gambar visual yang hanya ada pada gambar buku paket dan LKS yang digunakan. Sehingga pada akhirnya siswa hanya mampu berhayal dan berimajinasi terkait materi-materi yang disampaikan tersebut.
Salah satu peran teknologi pendidikan dalam memicu dan memacu proses belajar dalam mendesaian pesan-pesan dengan menerapkan teori-teori pembelajaran, menetapkan model, starategi, serta media pembelajaran yang tepat yang relevan dengan karakteristik siswa. Dengan demikian, pesan-pesan yang sudah dirancang dengan baik dan disampaikan dengan strategi yang tepat dan didukung dengan media yang ada misalnya internet, maka akan terjadi proses belajar yang diinginkan dan tujuan-tujuan pembelajaran yang sudah ditetapkan akan tercapai.

Berdasarkan permasalahan tersebut, maka dibutuhkan sebuah model pembelajaran inovatif yang mampu memadukan kegiatan pembelajaran tradisional dengan pembelajaran online yang disebut dengan model blended learning dengan menggunakan aplikasi media sosial Edmodo dalam rangka mendukung proses pembelajaran geografi. Model blended learning ini bertujuan menciptakan suasana pembelajaran akan lebih efektif dan efisien, serta agar dapat memotivasi siswa dalam kegiatan belajar siswa, terutama dalam kegiatan belajar mata pelajaran Geografi.

Bhonk dan Graham pada tahun 2006 (Rusman, Kurniawan, \& Riyana, 2012, p. 244) mengatakan bahwa pada umumnya "blended learning is the combination of instruction from two historically separate models of teaching and learning: Traditional learning systems and distributed learning systems. it emphasizes the central role of computer-based technologies in blended learning". Pendapat tersebut mengemukakan bahwa blended learning merupakan kombinasi dari model belajar yang terdiri dari pembelajaran tradisional dan pembelajaran dengan menggunakan bantuan komputer.

Hasil penelitian Dziuban, Hartman \& Moskal tahun 2004 (Erdem \& Kibar, 2014, p. 199) mengungkapkan bahwa blended learning menekankan pada pandangan terhadap pendekatan pedagogik, dimana pengkombinasian dapat meningkatkan keefektifan dan peluang dalam menjalin hubungan sosial dengan yang lainnya ketika 
berada di dalam kelas serta diperkuat lagi melalui pendekatan teknologi yang dapat memungkinkan keaktifan belajar siswa meningkat yang disebabkan melalui pembelajaran online.

Selanjutnya, hasil penelitian yang dilakukan oleh Marquis (2004) (Garrison \& Vaughan, 2008, p. 4) dimana dalam survei yang dilakukan telah menemukan bahwa 94\% dari dosen-dosen percaya bahwa pembelajaran yang menggunakan blended learning lebih efektif di bandingkan dengan pembelajaran yang hanya menggunakan satu model pembelajaran, misalnya seperti hanya menggunakan model pembelajaran konvensional saja atau hanya menggunakan pembelajaran berbasis online saja.

Dalam beberapa penelitian yang lain juga menemukan bahwa pembelajaran dengan menggunakan model blended learning dapat meningkatkan hasil belajar siswa (Hew \& Cheung, 2014, p. 5). Selain itu, Hew \& Cheung (2014, p. 4) juga mengungkapkan pembelajaran dengan menggunakan blended learning dapat juga meningkatkan komunikasi dengan siswa yang dimediasi menggunakan bantuan komputer baik secara syncronous maupun secara asyncronous. Penelitian tersebut menunjukan bahwa blended learning dapat mengantar siswa untuk memperoleh hasil belajar yang lebih baik, blended learning juga merupakan strategi yang efektif dan efisien dalam membantu siswa untuk mencapai tujuan pembelajaran.

Model blended learning yang dikembangkan bertujuan untuk mengatasi masalah keterbatasan waktu yang dimiliki dalam kegiatan pembelajaran. Model blended learning yang dikembangkan diharapkan dapat menjadi solusi alternatif strategi pembelajaran untuk mengatasi keterbtasan ruang dan waktu yang dimiliki oleh guru dalam mengajar.

Blended learning merupakan metode pembelajaran yang menggabungkan antara pembelajaran tatap muka dengan pembelajaran online, pembelajaran online yang digunakan dalam kegiatan ini, yaitu menggunakan aplikasi Edmodo yang merupakan media sosial yang khusus untuk pendidikan. Menurut Dzuban (Hew \& Cheung, 2014, p. 4) blended learning dapat meningkatkan rating hasil belajar siswa dibandingkan dengan hanya menggunakan pembelajaran tatap muka saja atau dengan pembelajaran online saja.

Blended learning sebagai suatu inovasi dalam pembelajaran memiliki prinsipprinsip yang mampu menjadi daya tarik dalam merancang kegiatan pembelajaran yang lebih baik. Adapun prinsip-prinsip dalam model blended learning sebagaimana diungkapkan (Garrison \& Vaughan, 2008, pp. 33-46) yaitu (1) rancana untuk membangun suasana pembelajaran yang akan mendorong komunikasi terbuka antar siswa dan guru, (2) membangun siswa untuk merefleksikan segala permasalahan yang dihadapi secara kritis, dan membangun kemandirian siswa, (3) mempertahankan komunitas untuk mencapai tujuan pembelajaran tertentu dan menjalin komunikasi yang bersifat kolaboratif, (4) mendorong dan mendukung perkembangan penemuan siswa dalam kegaiatan pembelajaran, (5) mengelola kolaborasi siswa, serta (6) konsep penilaian relevan dengan tujuan pembelajaran yang ditetapkan.

Adapun model-model penerapan blended learning dalam kegiatan pembelajaran terdiri dari beberapa model, sebagaimana di ungkapkan oleh Hauhey (1998) dalam (Rusman et al., 2012, pp. 251-252) mengelompokan model pembelajaran menjadi tiga model yaitu, (1) web course, (2) web centric course, (3) web enhanced course.

Darmawan (2014, p. 9) mengungkapkan bahwa kendaraan utama dalam proses pengajaran dan pembelajaran. Sementara Bersin (2004, p. 209) mengatakan "the LMS is the central administrative system to manage blended learning". LMS dalam kegiatan pembelajaran blended learning berperan dalam merancang kegiatan pembelajaran, memberikan izin kepada siswa untuk melakukan registrasi dan memberi izin untuk bergabung dalam kelas tertentu, menulis progres serta berperan juga dalam pemberian skor atau pemberian nilai. 
Hourdequen (2014) (Al-Said, 2015, p. 168) mengemukakan bahwa Edmodo merupakan aplikasi jaringan sosial yang memiliki tampilan yang hampir sama dengan jejaring sosial facebook, akan tetapi Edmodo menciptakan lingkungan belajar online bagi siswa untuk sharing diskusi terkait materi pemnbelajaran dengan tujuan untuk mencapai tujuan pembelajaran, sedangkan facebook tidak demikian halnya dengan Edmodo. Cauley (2013) (Monalisa \& Ardi, 2013, p. 221) mengemukakan Edmodo adalah sebuah website pendidikan yang digunakan untuk mengambil ide-ide dari jaringan sosial, kemudian ide tersebut di diskusikan agar menjadi lebih baik ketika akan disajikan dalam kelas.

Jared M. Carman (2005) (Syarif, 2012, p. 239) menjelaskan ada lima kunci untuk melaksanakan pembelajaran dengan menggunakan model blended learning, yaitu: (1) pembelajaran tatap muka (live event) pembelajaran mandiri (self-paced learning), (2) kolaborasi (collaboration), (3) penilaian/ pengukuran hasil belajar (assessment), (4) duakungan bahan belajar (performance support materials).

Joyce \& Weil (2010, pp. 15-16) mengemukakan terdapat lima komponen yang mesti ada dalam mengembangkan suatu model; (1) sintaks; (2) sistem sosial; (3) prinsip reaksi; (4) sistem pendukung; (5) dampak instruksional dan dampak pengiring. Selain itu, suatu model pembelajaran harus dilandasi oleh beberapa teori-teori pembelajaran, dalam penelitian ini teoriteori yang mendukung model ini yaitu; (1) konstruktivisme; (2) teori kognitif; (3) teori konstruktivisme sosial Vigotsky. Kemudian dari beberapa kriteria suatu model tersebut tersusun dalam suatu buku model. Buku model tersebut selanjuitnya di validasi oleh kedua ahli model bertujuan untuk mengetahui tingkat kelayakan model blended learning yang dikembangkan.

Kriteria kelayakan model blended learning dilihat dari perangkat pembelajaran, landasan teori yang melandasi, kunci blended learning dan komponen-komponen model.
Hourdequin (2014) (Al-Said, 2015) mengemukakan Edmodo merupakan perangkat sederhana $M$-learning yang digunakan untuk mempelajari materi atau konten yang biasanya dioperasikan menggunakan smartphone, alat tersebut disediakan untuk siswa dan guru untuk melakukan interaksi secara online dimanapun dan kapanpun. Pendapat tersebut masih spesifik yaitu hanya menekankan pada perangkat $\mathrm{M}$ learning yang artinya bahwa Emdodo hanya dapat diakses menggunakan perangkat mobile saja, padahal Edmodo sejatinya dapat diakses menggunakan apa saja dengan syarat dapat mengakses internet, maka Edmodo dapat dikunjungi oleh siapa saja dengan tujuan pembelajaran.

Sedangkan Cauley (2013) (Monalisa \& Ardi, 2013, p. 221) mengemukakan Edmodo adalah sebuah website pendidikan yang digunakan untuk mengambil ide-ide dari jaringan sosial dan kemudian ide tersebut disaring agar menjadi lebih baik dan lebih santun ketika akan disajikan dalam kelas. Edmodo sebagai platform jejaring sosial yang dikhususkan untuk pendidikan secara tidak langsung memiliki dampak pada sikap dan prilaku siswa dalam kegiatan pembelajaran. Hal tersebut yang menjadi pembeda dengan media sosial yang lainnya seperti facebook.

Keuntungan menggunakan Edmodo dalam kegiatan pembelajaran, yaitu (1) pernecanaan oleh guru, (2) memiliki fasilitas untuk memberikan reward kepada siswa atas pencapaian yang diperoleh.

Penggunaan Edmodo sebagai sarana pembelajaran online merupakan usaha yang dilakukan untuk dapat meningkatkan motivasi dan hasil belajar siswa dalam mata pelajaran geografi. Edmodo sebagai platform pembelajaran memiliki tampilan yang hampir sama dengan facebook dapat menjadi dorongan bagi siswa untuk senang dalam mengikuti kegiatan pembelajaran.

Prawiradilaga (2012, p. 31) mengemukakan bahwa "Educational technology is the study and ethical practice of facilitating learning and improving performance by creating, using, and managing appropriate techno- 
logical processes and resources". Sedangkan definisi teknologi pendidikan dalam perspektif terbaru tersebut menekankan pada beberapa hal penting, yaitu belajar dan kinerja, proses teknologis dan sumber, serta mengindahkan etika dan estetika dalam penggunaan teknologi masa kini. Namun dari definisi terbaru teknologi pendidikan tersebut, pada dasarnya masih memfokuskan tujuan untuk memfasilitasi kegiatan pembelajaran serta mengatasi permasalahan-permasalahan dalam kegiatan pembelajaran, sehingga kegiatan pembelajaran menjadi lebih efektif, efisien, menyenangkan dan meningkatkan kinerja.

Berdasarkan definisi tersebut, dapat disimpulkan bahwa teknologi pembelajaran adalah suatu disiplin ilmu atau bidang garapan, istilah teknologi pendidikan dari beberapa tahun mengalami perubahan atau pergantian istilah dari teknologi pendidikan menjadi teknologi pembelajaran begitu juga sebaliknya, hal ini merupakan salah satu langkah untuk memperbaiki serta mengkaji ulag definisi yang sudah dihasilkan sebelumnya. Teknologi pendidikan memiliki lima kawasan, yaitu: Desain, Pengembangan, Pemanfaatan, Pengelolaan, dan Evaluasi

Newby, Stepich, Lehman, Russell, \& Leftwich (2011, p. 73) mengungkapkan "Motivation is a common influence on human activities". Pendapat di atas mengungkapkan bahwa motivasi merupakan suatu kondisi yang dapat mempengaruhi aktivitasaktivitas manusia dalam menjalankan kehidupan. Kondisi tersebut bisa datang dari dalam diri seseorang atau bisa juga datang dari luar seseorang yang dapat menimbulkan perubahan dalam diri seseorang. Karena motivasi dapat memberikan kontribusi langsung terhadap kegiatan belajar siswa, baik dengan memberikan rasa fokus terhadap siswa untuk belajar untuk mencapai tujuan belajar yang diinginkan serta meningkatkan usaha secara maksimal agar mencapai tujuan yang diinginkan (Newby et al., 2011)

Menurut Atkinson, motivasi dijelaskan sebagai suatu tendensi seseorang untuk berbuat yang meningkat guna menghasilkan satu hasil atau lebih pengaruh. Sedangkan Bernard memberikan pengertian motivasi sebagai fenomena yang dilibatkan dalam perangsangan tindakan kearah tujuan-tujuan tertentu (Prawira, 2013, p. 319). Motivasi adalah proses mendorong dan mempertahankan tujuan dengan mengarahkan prilaku (Schunk, 2012, p. 475).

Berdasarkan beberapa pendapat tersebut, maka kaitan motivasi dalam maudel blended learning yang menggunakan Edmodo yaitu bagaimana kemudian dengan menggunakan Edmodo akan tercipta suasana yang akrab, baik antara siswa dengan guru atau bahkan antara siswa dengan siswa yang lain, sehingga aktifitas pembelajaran selain menarik bagi siswa juga dapat meningkatkan motivasi dalam belajar.

Newby et al. (2011, p. 73) mengungkapkan motivasi dapat dikategorikan menjadi dua, yaitu instinsik dan ekstrinsik. Motivasi intrinsik merupakan motif-motif yang berasal dari dalam diri seseorang, sehingga tidak perlu lagi ada ransangan dari luar untuk mengaktifkannya. Sementara motivasi ekstrinsik, yaitu motivasi yang berasal dari luar diri seseorang tersebut.

Motivasi ekstrinsik adalah motifmotif yang aktif dan berfungsi karena ada dorongan yang berasal dari luar. Motivasi ekstrinsik dapat juga dikatakan sebagai bentuk motivasi yang di dalamnya aktifitas belajar dimulai dan diteruskan berdasarkan dorongan dari luar yang tidak secara terus menerus berkaitan dengan aktivitas belajar.

Adapun faktor yang mempengaruhi motivasi belajar sebagaimana diungkapkan (Muhibbin, 2006), yaitu: (1) guru, (2) orang tua dan keluarga, (3) masyarakat dan lingkungan. Sementara Joe \& Emaloe (1994, p.78-106) menambahkan faktor yang mempengaruhi motivasi belajar yaitu: (1) konten. (2) lingkungan, (3) guru, (4) komunitas belajar, dan (5) siswa.

\section{Metode}

Penelitian ini menggunakan pendekatan kuantitatif dengan jenis penelitian 
pengembangan Research and Development (R\&D) yang mengacu pada model pengembangan ADDIE yang diadopsi dari Branch (2009, p. 4) yang memiliki komponen yang terdiri dari langkah-langkah pengembangan (analysis, design, development, implementation, E evaluation).

Penelitian ini dilaksanakan selama empat bulan mulai dari 8 Februari sampai dengan tanggal 30 Mei 2016 di SMA Assalaam Sukoharjo. Subjek uji coba dalam penelitian ini adalah ahli model sebanyak dua orang, ahli materi dua orang, dan siswa kelas XI IPS SMA Assalaam yang berjumlah 17 siswa.

Sebelum melakukan pengembangan model blended learning, dilakukan analisis kebutuhan untuk menentukan karakteristik materi yang akan dikembangkan. Anlisis kebutuhan materi tersebut didasarkan pada kurikulum dan materi yang berlaku dalam sekolah tersebut. Selanjutnya, tahap desain dilakukan perencanaan model blended learning, yang meliputi; (1) kegiatan merancang sintaks yang merupakan fase-fase dalam kegiatan pembelajaran; (2) merancang sistem sosial, yang mencakup gambaran situasi pembelajaran yang diinginkan untuk membangun interaksi antara siswa dengan siswa dan guru dengan siswa. Sehingga terbentuk komunikasi yang harmonis antara siswa dengan guru maupun antara siswa dengan siswa; (3) merancang prinsip reaksi, yang dapat memberikan gambaran mengenai reaksi guru terhadap pendapat siswa atau ide-ide siswa; (4) sistem pendukung yang mencakup gambaran atau kondisi yang diperlukan agar model blended learning dapat dijalankan dengan baik; (5) merancang dampak instruksional dan dampak pengiring, yang mencakup gambaran akibat langsung kegiatan pembelajaran dengan model yang dikembangkan. Rancangan dampak pengiring merupakan akibat tidak langsung atau akibat jangka panjang. Selanjutnya merancang perangkat pembelajaran RPP.

Pata tahap pengembangan (development) dilakukan proses realisasi model blended learning yang meliputi pembuatan rencana pelaksanaan pembelajaran (RPP), membuat bahan ajar, dan kegiatan pembelajaran. Pada tahap implementasi (implementation) yaitu pelaksanaan kegiatan pembelajaran yang dilakukan di SMA Assalaam Sukoharjo, Solo. Pada tahap evaluasi yaitu dilakukan validasi oleh dua ahli materi dan dua ahli model, kegiatan pretest dan postest dan respon siswa terhadap penggunaan model blended learning.

Teknik pengumpulan data yang digunakan dalam penelitian ini berupa wawancara, kuesioner, dan tes. Instrumen yang digunakan dalam penelitian ini adalah angket, wawancara, melakukan observasi dan tes hasil belajar. Instrumen angket terdiri dari tiga jenis, yaitu angket untuk ahli model dan ahli materi, serta angket untuk respon siswa, digunakan untuk memberikan penilaian tentang tingkat kelayakan suatu produk yang dikembangkan berdasarkan pada aspek-aspek tertentu. Angket yang dibuat terdiri dari empat skala yang mengacu pada buku Mardapi (2008, p. 123) yaitu terdiri dari (4) sangat layak, (3) layak, (2) tidak layak, (1) sangat tidak layak. Angket untuk ahli materi terdiri dari penilaian kelayakan dari aspek pembelajaran dan kebenaran isi pembelajaran yang disajikan. Sedangkan dari ahli model blended learning terdiri dari; (1) aspek perangkat pembelajaran; (2) kunci model blended learning; (3) aspek teori yang melandasi; (4) aspek komponen-komponen model yang terdiri dari lima komponen model, yaitu; (1) sintaks; (2) sistem sosial; (3) prinsip reaksi; (4) sistem pendukung; (5) dampak instruksional dan dampak pengiring.

Teknik analisis data yang digunakan dalam mengolah data yang diperoleh dalam penelitian ini menggunakan teknik analisis data kualitatif dan kuantitatif, yaitu analisis data deskriptif kualitatif untuk kelayakan media dan pengaruh media terhadap hasil belajar. Untuk mengubah skor penilaian kedalam data kualitatif, dalam penelitian ini teknik analisis data menggunakan skala likert, maka diguna- 
kan pedoman skala penilaian instrumen dan kriteria penilaian instrumen berikut.

Tabel 1. Pedmoan Skala Penlaian Instrumen

\begin{tabular}{lc}
\hline \multicolumn{1}{c}{ Data Kuantitatif } & Penilaian \\
\hline Sangat Baik & 4 \\
Baik & 3 \\
Kurang & 2 \\
Sangat Kurang & 1 \\
\hline
\end{tabular}

Tabel 2. Konversi Nilai skala 4

\begin{tabular}{rcl}
\hline \multicolumn{1}{c}{ Rentang Skor } & Nilai & \multicolumn{1}{c}{ Kategori } \\
\hline $\mathrm{x} \geq \bar{x}+1 \mathrm{SBi}$ & 4 & Sangat Layak \\
\hline $\bar{x}+1 \mathrm{SBi}>\mathrm{x} \geq \bar{x}$ & 3 & Layak \\
\hline $\bar{x}>\mathrm{x} \geq \bar{x}-1 \mathrm{SBi}$ & 2 & Kurang Layak \\
\hline $\mathrm{x}<\bar{x}-1 \mathrm{SBi}$ & 1 & Sangat Kurang Layak \\
\hline
\end{tabular}

Untuk memperoleh data tentang keefektifan model blended learning dalam meningkatkan hasil belajar siswa, maka dapat dilihat melalui hasil pretest dan postest siswa kelas XI yang dilakukan oleh 17 orang siswa setelah menggunakan model blended learning.

\section{Hasil dan Pembahasan}

Pada tahap analisis dilakukan analisis kinerja, dan analisis kebutuhan. Tahap ini bertujuan untuk analisis permasalahan yang dihadapi dan solusi seperti apa yang dibutuhkan untuk memecahkan masalah tersebut. Berdasarkan hasil anlisis kinerja ditemukan bahwa dalam kegiatan pembelajaran ditemukan (1) kurangnya pemanfaatan metode dalam kegiatan pembelajaran, (2) rendahnya motivasi siswa dalam kegiatan belajar memerlukan model dan metode pembelajaran yang bervariasi, (3) fasilitas yang memadai tidak dimanfaatkan dengan baik oleh guru dalam memfasilitasi siswa. Adapun analisis kebutuhan yang diperoleh, yaitu diperlukan (1) model pembelajaran yang bervariasi agar tercipta suasana pembelajaran yang tidak membosankan, (2) materi yang disajikan juga perlu disampaikan dengan menggunakan media pembelajaran yang inovatif, (3) materi yang didesain perlu disajikan menggunakan pembelajaran online, seperti halnya media sosial.

Pada tahap desain dilakukan perancangan model blended learning, yang meliputi teori yang melandasi model, kunci blended learning, dan merancang setiap komponen-komponen model (sintaks, aspek sosial, prinsip sosial, sistem pendukung, dan dampak instruksional dan dampak pengiring).

Pada tahap pengembangan dilakukan realisasi model blended learning. Pada tahap realisasi model blended learning, bahwa kegiatan pembelajaran secara umum dibagi menjadi tiga kegiatan pokok, yaitu kegiatan face to face learning, online learning, dan offline. Kegiatan face to face merupakan kegiatan konvensioanal yang dilaksanakan dalam kelas menggunaan metode ceramah, sedangkan online dilakukan dalam kegiatan pembelajaran dalam Edmodo yang meliputi kegiatan diskusi online, menjawab tugas, mendownload materi, dan mengerjakan kuis-kuis yang tersedia di Edmodo. Sedangakn kegiatan pembelajaran offlline meliputi kegiatan membaca materi di rumah, mengerjakan tugas-tugas kelompok di rumah, dan lain sebagainya. Adapun pembagian kegiatan dalam model blended learning dapat dilihat pada Gambar 2.

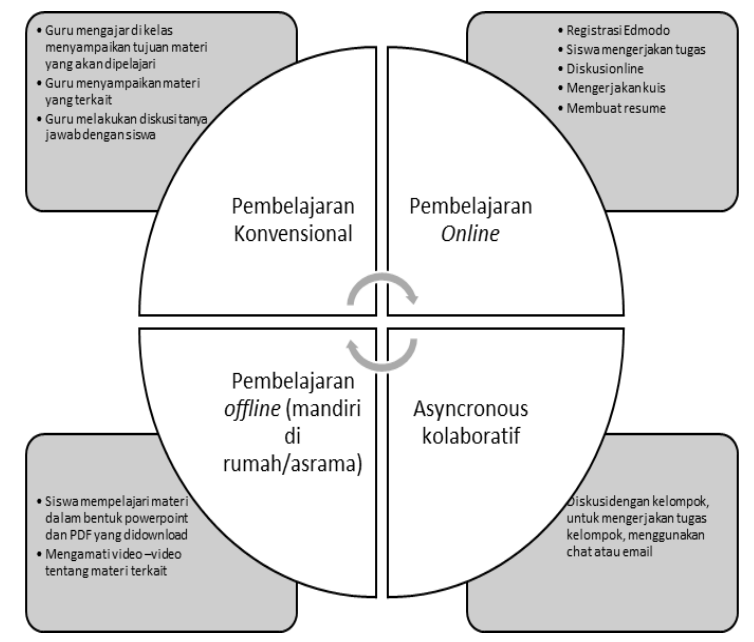

Gambar 2. Model Blended Learning

Komponen-komponen yang akan divalidasi oleh ahli model yaitu meliputi 
aspek perangkat pembelajaran, yang memuat mengenai rencana pelaksanaan pembelajaran, tentang kesesuaian isi materi sebagai pendukung model blended learning. Selanjutnya kunci blended learning yang menyangkut hal-hal apa saja yang harus ada dalam kegiatan belajar model blended learning. Selanjutnya teori yang mendukung model blended learning. Kemudian aspek selanjutnya yaitu komponen-komponen model yang meliputi sintaks, sistem sosial, prinsip reaksi, sistem pendukung, dampak instruksional dan dampak pengiring.

Selanjutnya dilakukan validasi oleh ahli model, validator model terdiri dari dua ahli model, masing memberikan penilaian terhadap model yang dikembangkan.

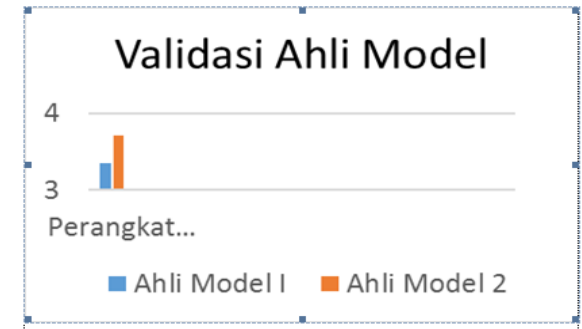

Gambar 3. Hasil Penilaian Ahli Model Pada Aspek Perangkat Pembelajaran

Pada aspek perangkat pembelajaran, berdasarkan hasil penilaian kedua ahli model diperoleh rerata skor secara keseluruhan sebesar 3,58. Hasil tersebut kemudian dikonversikan dalam skala 4, sehingga hasil penilaian tersebut dapat disimpulkan dalam kategori sangat baik.

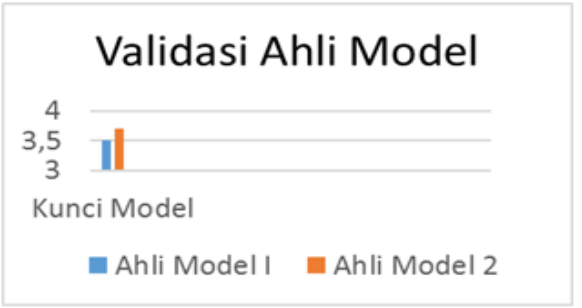

Gambar 4. Hasil Penilaian Ahli Model pada Aspek Kunci Model Blended

Pada aspek kunci model blended learning, berdasarkan hasil penilaian kedua ahli model diperoleh rerata skor secara keseluruhan sebesar 3,6. Hasil tersebut kemudian dikonversikan dalam skala 4 , sehingga hasil penilaian tersebut dapat disimpulkan dalam kategori sangat baik.

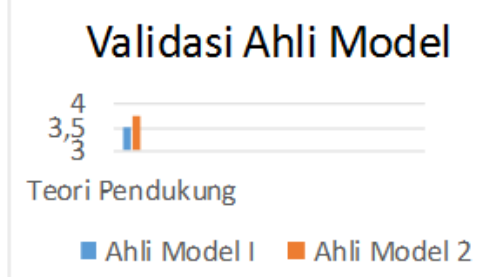

Gambar 5. Hasil Penilaian Ahli Model Pada Aspek Teori yang Mendukung

Pada aspek teori yang mendukung, berdasarkan hasil penilaian kedua ahli model diperoleh rerata skor secara keseluruhan sebesar 3,63. Setelah dikonversikan dalam skala 4, sehingga hasil penilaian tersebut dapat disimpulkan dalam kategori sangat baik.

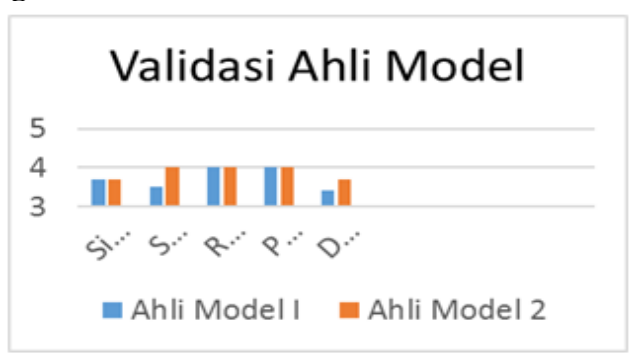

Gambar 6. Hasil Penilaian Ahli Model pada Aspek Komponen Model

Ket:

$\mathrm{Si}=$ Sintaks

$\mathrm{S}=$ Sistem sosial

$\mathrm{R}=$ Prinsip reaksi

$\mathrm{P}=$ Sistem pendukung

$\mathrm{D}=$ Dampak insturksional

Pada aspek Komponen model berdasarkan hasil penilaian kedua ahli model diperoleh pada aspek sintaks memperoleh rerata skor 3,71, aspek sosial memperoleh rerata 3,75 , prinsip reaksi memperoleh rerata skor 4, sistem pendukung memperoleh rerata skor 4, dampak instruksional memperoleh rerata skor 3,57. Sehingga secara keseluruhan skor yang diperoleh yaitu sebesar 3,80. 
Tabel 3. Hasil Penghitungan SPSS

\begin{tabular}{|c|c|c|c|c|c|c|c|c|}
\hline \multicolumn{9}{|c|}{ Paired Samples Test } \\
\hline & \multicolumn{5}{|c|}{ Paired Differences } & \multirow[b]{3}{*}{$\mathrm{t}$} & \multirow[b]{3}{*}{$\mathrm{df}$} & \multirow{3}{*}{$\begin{array}{l}\text { Sig. (2- } \\
\text { tailed) }\end{array}$} \\
\hline & \multirow[b]{2}{*}{ Mean } & \multirow{2}{*}{$\begin{array}{c}\text { Std. } \\
\text { Deviation }\end{array}$} & \multirow{2}{*}{$\begin{array}{c}\text { Std. Error } \\
\text { Mean }\end{array}$} & \multicolumn{2}{|c|}{$\begin{array}{l}95 \% \text { Confidence } \\
\text { Interval of the } \\
\text { Difference }\end{array}$} & & & \\
\hline & & & & Lower & Upper & & & \\
\hline Pair 1 pretest - postest & $-34,35294$ & 9,27996 & 2,25072 & $-39,12426$ & $-29,58163$ & $-15,263$ & 16 & ,000 \\
\hline
\end{tabular}

Selanjutnya, sebagai pendukung model blended learning, materi yang telah disusun dilakukan validasi juga, tujuannya untuk menghasilkan materi pembelajaran yang layak untuk digunakan dalam kegiatan pembelajaran, karena disusun dari berbagai sumber. Aspek-aspek materi yang akan divalidasi meliputi aspek pembelajaran dan kebenaran isi pembelajaran.

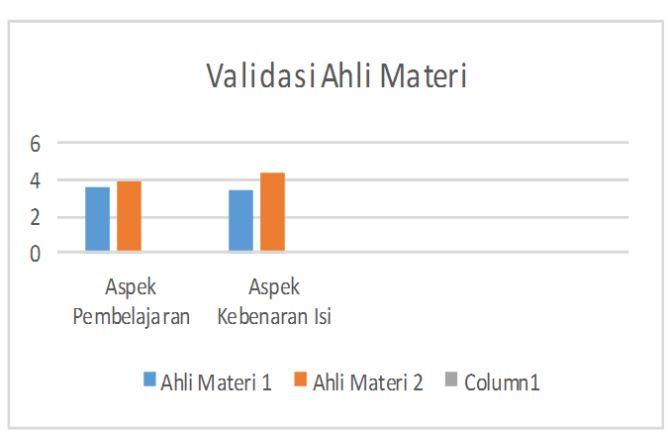

Gambar 7. Hasil Penilaian Ahli Materi

Adapun hasil penilaian dua ahli materi yaitu, pada aspek pembelajaran memperoleh rerata skor sebesar 3,71, dan pada aspek kebenaran isi pembelajaran memperoleh 3,58.

Untuk mengukur efektifitas model yang dikembangkan, maka siswa diberikan pretest dan postest. Kegiatan pretest dan postest diberikan kepada siswa kelas XI SMA Assalaam Sukoharjo sebanyak 17 orang.

Adapun hasil pretest yang diperoleh dari 17 orang siswa yaitu 55,29 sedangkan postest sebesar 89,65. Untuk mengetahui taraf signifikansinya digunakan SPSS, berikut ini tabel hasil yang diperoleh menggunakan SPSS yang disajikan pada Tabel 3.
Berdasarkan hasil perhitungan dengan menggunakan SPSS nilai signifikansi lebih kecil dari 0,05, sehingga terdapat perbedaan hasil belajar sebelum dan setelah menggunakan model blended learning. Hasil perhitungan diperoleh signifikansi sebesar 0,000, hal tersebut menunjukan bahwa nilai signifikansi yang diperoleh lebih kecil dibandingkan 0,05. Maka dengan demikian Ho ditolak dan Ha diterima.

Selanjutnya, angket respon siswa diberikan dengan tujuan untuk mengetahui respon siswa terhadap model blended learning yang dikembangkan. Angket respon siswa diberikan pada pertemuan terakhir uji coba lapangan.

Tabel 4. Hasil Respon Siswa

\begin{tabular}{lcc}
\hline Skala & Frekruensi & Persentase \\
\hline Sangat Baik & 13 & $76 \%$ \\
Baik & 4 & 245 \\
Tidak Baik & 0 & $0 \%$ \\
Sangat Tidak Baik & 0 & $0 \%$ \\
\hline
\end{tabular}

Berdasarkan hasil pada Tabel 4 pada sebanyak 13 siswa memberikan respon sangat baik untuk kegiatan pembelajaran menggunakan model blended learning, kemudian sebanyak 4 siswa memberikan baik penggunaan model blended learning. Dengan demikian, maka secara keseluruhan siswa memberikan respon positif terhadap penggunaan model tersebut dalam kegiatan pembelajaran.

\section{Simpulan}

Model blended learning menggunakan Edmodo dikembangkan berdasarkan 
prosedur dan tahapan-tahapan yang sudah ditetapkan mulai dari tahap analisis hingga tahap evaluasi yang dilakukan oleh ahli materi dan ahli model, sehingga menghasilkan produk berupa model blended learning yang memiliki tingkat valid, layak, dan efektif. Model yang dihasilkan berupa pola kegiatan pembelajaran yang mengkombinasikan pembelajaran tatap muka (face to face), pembelajaran online menggunakan media sosial Edmodo, dan kegiatan pembelajaran mandiri (offline).

Model blended learning memperoleh tingkat kevalidan dan kelayakan dengan kriteria sangat layak didasarkan dari hasil validasi dua ahli materi dan dua ahli model dengan nilai skor rata-rata untuk materi sebesar 3,65 yang diperoleh dari dua aspek yaitu perangkat pembelajaran dan aspek kebenaran isi materi yang disajikan. Dengan demikian, materi tersebut layak digunakan dalam penelitian ini. Adapun validasi model yang dilakukan oleh dua ahli model memberikan penilaian terhadap model yang dikembangkan, hasil validasi kedua validator model mendapatkan skor 3,64 dengan kriteria sangat baik/sangat layak. Hasil ini diperoleh dari tiga aspek, aspek perangkat pembelajaran, aspek kunci model blended learning dan aspek komponen-komponen model blended learning. Model blended learning yang dikembangkan sudah memenehui tingkat efektif didasarkan pada hasil yang diperoleh dari uji coba lapangan, yaitu dengan memberikan pretest dan postest. Hal tersebut untuk membandingkan hasil penggunaan model blended learning yang dikembangkan. Uji lapangan dilakukan di SMA Assalaam Sukoharjo pada kelas XI IPS Putra dan XI IPS Putri.

Berdasarkan hasil tes, maka rerata pretest sebesar 55,29 sedangkan pada kegiatan postest meningkat menjadi 88,65 , sedangkan taraf signifikansinya lebih dari 0,05 yang dihitung menggunakan spss. Respon siswa terhadap kegiatan pembelajaran menggunakan model blended learning secara umum mendapat respon positif dari siswa. Keterlaksanaan model blended learning dalam kegiatan pembelajaran sebagian besar terlaksana dengan baik, rerata skor yang diperoleh yaitu sebesar 3,14.

Berangkat dari hasil penelitian yang diperoleh, maka disarankan kepada para praktisi kependidikan seperti para guru untuk dapat menggunakan model blended learning, karena dengan menggunakan blended learning, selain dapat meningkatkan hasil belajar dan motivasi siswa dalam kegiatan pembelajaran, juga dapat membangun kemandirian belajar bagi siswa dalam belajar. Oleh karena itu, bagi para guru untuk dapat memanfaatkan kemajuan teknologi dan komunikasi untuk digunakan dalam merancang kegiatan pembelajaran yang lebih menarik.

\section{Dafar Pustaka}

Al-Said, K. M. (2015). Students' perceptions of Edmodo and mobile learning and their real barriers towards them. TOJET: The Turkish Online Journal of Educational Technology, 14(2). Retrieved from http:/ / www.tojet.net/articles/v14i2/ 14220.pdf

Asosiasi Penyelenggara Jasa Internet Indonesia. (2014). Profil pengguna internet Indonesia. Jakarta: APJII.

Bersin, J. (2004). The blended learning book: best practices, proven methodologies, and lessons learned. San fransisco: Pfeiffer.

Branch, R. M. (2009). Instructional design: the ADDIE approach. New York: Springer.

Darmawan, D. (2014). Pengembangan elearning: teori dan desain. Bandung: Remaja Rosdakarya.

Erdem, M., \& Kibar, P. N. (2014). Students' opinions on facebook supported blended learning environment. TOJET: The Turkish Online Journal of Educational Technology, 13(1). Retrieved from http:/ / www.tojet.net/articles/v13i1/ 13118.pdf 
Garrison, D. R. (D. R., \& Vaughan, N. D. (2008). Blended learning in higher education: framework, principles, and guidelines. San Francisco: Jossey-Bass.

Hew, K. F., \& Cheung, W. S. (2014). Using blended learning: evidence-based practices. New York: Springer.

Joyce, B. R., \& Weil, M. (2010). Models of teaching. New York: Allyn \& Bacon.

Mardapi, D. (2008). Teknik penyusunan instrumen tes dan nontes. Yogyakarta: Mitra Cendikia Press.

Monalisa, \& Ardi, H. (2013). Using "edmodo" educational social network in teaching english for high school students. Journal of English Language Teaching, 2(1), 220-225. Retrieved from http:/ / ejournal.unp.ac.id/index.php/ jelt/article/view/2609

Muhibbin, S. (2006). Psikologi belajar. Jakarta: PT. Raja Grapindo Persada.

Nee, C. K. (2014). The effect of educational networking on students' performance in biology. International Journal on Integrating Technology in Education (IJITE), 3(1), 21-41. https:// doi.org/10.5121/ijite.2014.310 2
Newby, T. J., Stepich, D., Lehman, J., Russell, J. D., \& Leftwich, A. T. (2011). Educational technology for teaching and learning (4th ed.). Boston: Pearson.

Prawira, P. A. (2013). Psikologi pendidikan dalam perspektif baru. Yogyakarta: Arruz Media.

Prawiradilaga, D. S. (2012). Wawasan teknologi pendidikan. Jakarta: Kencana.

Rusman, Kurniawan, D., \& Riyana, C. (2012). Pembelajaran berbasis teknologi informasi dan komunikasi: mengembangkan profesionalisme guru. Jakarta: Rajawali Pers.

Schunk, D. H. (2012). Learning theories an educational perspektif (teori teori pembelajaran: perspektif pendidikan) (terjemahan Eva Hamdiah dan Rahmat Fajar). Yogyakarta: Pustaka Pelajar.

Soegimo, D., \& Ruswanto. (2009). Geografi untuk SMA. Jakarta: CV Mefi Caraka.

Syarif, I. (2012). Pengaruh penerapan model blended learning terhadap motivasi dan prestasi belajar siswa SMKN 1 Paringin. Thesis. Tidak diterbitkan. Universitas Negeri Yogyakarta. Retrieved from http:/ / eprints.uny.ac.id/8221/ 